\title{
Giorgio Agamben, Pitat i Jezus [Pilate and Jesus], Cracow: Wydawnictwo Znak, 2017, p. 128
}

DOI: http://dx.doi.org/10.12775/RF.2016.046

Giorgio Agamben is an incredibly fertile philosophical thinker. Starting with the 1970s and his debut with L'uomo senza contenuto (Man Without Content), new books left his literary workshop at short intervals, among which we should first of all mention the tetralogy opened with Homo Sacer. Sovereign Power and Bare Life. It is a multifaceted analysis in which Agamben looks for connections between a democratic and a totalitarian state, with an emblematic figure represented by homo sacer ("a holy man") - a refugee or an outlaw - as a kind of a «byproduct» of both these political systems which, in the judgement of the Italian philosopher, is largely based on the biopolitical paradigm of holding power. The consecutive two parts of the tetralogy, considered as one due to their close thematic affinity, discuss the complex and enigmatic relationships occurring between the legislative and executive power (State of emergency) and try to demonstrate that the structures of Western political models mimic the vertical structure of Christianity: God-sovereign - man (the thus far untranslated Il regno e la gloria). In the third part of the series, Remnants of Auschwitz, the philosopher analyses the character of the "Muslim" from the concentration camps, as well as the function of the testimony given by him. The fourth and last part, L'uso dei corpi, is a collection of essays describing key categories of Agamben's philosophy with the concept of "the form of life" at the lead. Doubtlessly, the enumerated works of the Italian thinker, forming a seemingly inconsistent and loose publishing sequence, constitute only a small part of his fruitful oeuvre. Many other titles oscillate around the axis of his philosophical prose, such as the collections Nudities or Profanations, mostly not translated into Polish.

Recently (in February 2017) another book by the Italian philosopher, Pilate and Jesus, ${ }^{1}$ was published by the Znak publishing house, prompting a series of discussions and debates (it is worth mentioning, for example, the essay, Spotkanie, do którego nie doszło [The Meeting Which Did

\footnotetext{
1 Italian ed.: Giorgio Agamben, Pilato e Gesù. Roma: Nottetempo, 2013.
} 
Not Take Place] by Agata Bielik-Robson). Despite the title which would rather place the book amidst theological sciences, it is a continuation of the topic from the second part of the philosopher's tetralogy, namely the relation between politics (history) and theology, or rather between power as temporal secular order and the order of salvation.

The first part of this little book focuses explicitly on the character of Pilate: his silhouette passed on by the evangelists, highlighting his indecision, apocryphal descriptions and other non-biblical passages or legends (which sometimes depicted him as a positive figure), as well as some great works of literature (The Master and Margarita by Mikhail Bulgakov). Undoubtedly, the author's knowledge of literature concerning the character is a proof of his erudition.

However, the part devoted to Pilate's profile remains in the background of the author's reflections. In the largest part of the book, Agamben analyses in detail the trial of Jesus (it is worth mentioning that the thinker is a lawyer and classical philologist by education), where "it is the world of facts that must judge the world of truth, the temporal kingdom that must pronounce judgement on the eternal kingdom", reaching a controversial conclusion that ... the judgement on Jesus was never passed. Because in accordance with the specificity of the Roman law the moment the judge is assured of the defendant's innocence ("I do not find any guilt in him") he should pass a sentence of acquittal or the trial ought to be suspended for the purpose of an investigation. However, such a sentence is not passed (in the form stipulated by the Roman law), and the proceedings described in the pages of the Gospel lose all the traits of a judicial trial sensu stricte, becoming rather its simulacrum.

In Agamben's opinion Jesus was not so much convicted as he was "turned in". This is perhaps the most surprising moment in the book, which for Agamben bears a great symbolic significance. He is polemising with Dante, who attempted to legitimise the Roman Empire by placing an emphasis specifically on the legitimacy of the court and judgement - due to the fact that Pilate, as a judge appointed by the emperor, could judge practically every person and the cross of Christ as a punishment could have a redemptive character. This very combination of the two "grounds", historical and theological, of a secular court which is at the same time a divine court, is what concerns Agamben the most.

In the Italian thinker's opinion, Pilate standing before Jesus, judging not only a man placed at a particular moment of human history but also God implementing the divine plan of salvation, is faced with the dilemma regarding the extent to which Jesus's words on the extraterrestrial nature of his kingdom («My Kingdom is not of this world») can influence the earthly order of power. Especially since its transcendental character is at the same time immanent («The Kingdom of God is in you»). 
Agamben s book should be read in this very spirit in concord with his consistently realised philosophical project contained in his previous works. If politics were to imitate certain theological beliefs, according to Agamben, it would do so by some continuous care to make certain whether the intentional order that governments and administrations place on their citizens is respected by them. Just like God, who also stands above the world whilst at the same time being beyond it, is still present in it - in the form of a plan that he has for his creation. In the trial of Jesus the philosopher sees an «allegory of our times,» and the reflection on the trial, full of erudite references to the skilled experts of the Roman law, is an implicit reflection on what the political and social order would look like today if this link between theology and politics, existing in the form of political theology, was not made.

Although the book «Pilate and Jesus» counts less than 90 pages of a small format (the rest of the publication is an essay by Mateusz Burzyk and Mikolaj Ratajczak), it retains all the characteristic features of Agamben >s philosophical prose: a slow stratification and interweaving of plots, very distant and bold comparisons (the trial of Jesus - the trial of F. Kafka>s character), it is a multifaceted book (the work can be read only at the level of the trial of Jesus without referring to the broader whole), often enigmatic, which certainly does not facilitate reading. All of these qualities certainly make up one whole and are also evident in this publication: the book is provocative, poses questions which are not that obvious at all, and the answers that it tries to give are not written from the ex cathedra perspective which is so frequent in the philosophical works of many researchers.

As was already mentioned, the publisher has attached to the book an essay by Mateusz Burzyk and Mikolaj Ratajczak entitled Posłowie: człowiec nie osadził Boga, Bóg nie osadzi świata. Giorgio Agamben i teologia polityczna [Afterword: Man Has not Judged God, God Will Not Judge the World. Giorgio Agamben and Political Theology]. Not only does the essay introduce one to the philosophical writings by the Italian philosopher in a synthetic way but also tries to incorporate his work into a broader context of political theology, which as a scholarly discipline has developed quite recently in response to the work by Carl Schmitt and the activity of the Frankfurt school. It also lists the distinctive features that distinguish Agamben's works from other authors dealing with the topic of political theology such as the fact that the Italian philosopher's intention is not to call for dechristianisation but rather is a reminder that "already someone before them [the fathers of the Church - D.W.] attempted to present Jesus as the king and the judge of the world - it was his accusers and torturers.» It remains an open question how much this fact served both the institutional dimension of the Church and the various forms of authority which, if we were to believe what the political theology says, 
reflects this hierarchical structure of the Church. In a word, this essay is undoubtedly an indispensable aid for an uninformed reader.

Surely, anyone who reads the book «Pilate and Jesus» and the accompanying essay, regardless of whether they share the views of political theology or not, will not be disappointed. The first group will be provided with arguments for finding degenerated structures of governing over the citizens in the secular model of power, the second one - an opportunity to formulate counter-arguments and consolidate their own vision of the state. However, to both groups, it will above all be an opportunity to reflect on one of the most important, if not indeed the most important, judicial proceedings that have taken place in the history of the world. 